\title{
Not All Currency Traders Believe in Unfettered Free Markets: Currency Speculation and Market Intervention in Hong Kong*
}

\author{
Leong $\mathrm{H}$. Liew and Harry $\mathrm{X}$. Wu
}

ABSTRACT Expectations and beliefs are important forces that can influence financial markets. Using results from a survey, this article examines the beliefs of currency traders in Hong Kong's financial institutions regarding the RMB and HK\$/US\$ pegs. In particular, it examines the attitudes of these currency traders towards the intervention by the Hong Kong Monetary Authority (HKMA) in Hong Kong's stock and futures markets to defend the HK\$/US\$ peg during the Asian crisis in 1998. Contrary to expectation, not all currency traders in Hong Kong were diehard devotees of the free market and more were in support of the intervention than against. Degree of identification with Hong Kong was found to be important, influencing attitudes towards government intervention. An inference from the survey is that the intervention was popular with Hong Kong residents and that future intervention by the HKMA is likely if faced with similar speculative attacks on the HK\$.

Our age is not more dangerous - not more risky - than those of earlier generations - but the balance of risks and dangers has shifted. We live in a world where hazards created by ourselves are as, or more, threatening than those that come from the outside. $^{1}$

Currency speculators, sensing speculative opportunities offered by the Asian financial crisis, launched several concerted attempts to attack the Hong Kong dollar (HK\$) in 1997 and 1998. The most serious of these attacks occurred in August 1998. The survival of the HK\$/US\$ peg at the fixed rate of HK\$7.80 to US\$1 was seen as sine qua non for the economic and political stability of Hong Kong after its return to Chinese sovereignty, and concerns were raised at that time as to whether the peg could survive the possible devaluation of the Chinese renminbi (RMB), which was widely forecast by some financial analysts. ${ }^{2}$ Many analysts believed that RMB devaluation would make Hong Kong uncompetitive vis-à-vis mainland China and force Hong Kong to devalue. However,

\footnotetext{
* The authors wish to thank Fu Lei and Lam Chui Sing for assistance in carrying out the survey and Professor Tsang Shu Ki and Dr. John Lee for advice and suggestions. Financial support from the Australian Research Council is gratefully acknowledged.

1. Anthony Giddens, "Lecture 2-risk-Hong Kong," Reith Lectures (BBC, 1999).

2. For an argument against RMB devaluation, see Leong H. Liew, "A political-economy analysis of the Asian financial crisis," Journal of the Asia Pacific Economy, Vol. 3, No. 1 (1998), pp. 322-23. An analysis on the factors that determine the value of the RMB is given in Harry X. Wu, "Reform of China's foreign exchange rate regime and its implications in the light of the Asian financial crisis," MOCT-MOST, Vol. 8 (1998), pp. 81-105.
} 
Wei et al. using a computable general equilibrium (CGE) model calculated that RMB devaluation would have a negligible effect on Hong Kong's foreign trade. This is because the increase in mainland China's exports to the rest of the world through Hong Kong as a result of RMB devaluation would more or less compensate for the fall in Hong Kong's direct and indirect exports to mainland China and the increase in Hong Kong's direct imports from mainland China. ${ }^{3}$ Wei et al. argued that the fear in Hong Kong of RMB devaluation was mainly psychological. Other analysts reported that concerns over the stability of the peg was the major factor behind Chinese premier Zhu Rongji's decision not to devalue the RMB. Since expectations and beliefs are important forces that can influence financial markets, it would be instructive to examine the beliefs of currency traders in Hong Kong's financial institutions regarding the RMB and HK\$/US\$ peg. A survey of currency traders and related staff involved in currency trades of financial institutions in Hong Kong was therefore undertaken for this purpose. Wei et al. undertook a survey of financial participants on this question as part of their research on the HK\$/RMB link but they interviewed only seven people. ${ }^{4}$ Our sample of traders interviewed is many times larger.

Hong Kong has long been regarded as one of the world's freest economies and the Hong Kong Monetary Authority (HKMA) was severely criticized by many financial and business commentators, including those from The Economist and Far Eastern Economic Review, for intervening in Hong Kong's financial markets to ward off speculative attacks on the HK\$. But what do the currency traders think? In an industry where the free market as an article of faith is publicly expressed by the participants, is there a divergence between public standpoint and private belief? The job of the HKMA in thwarting speculators through market intervention would be made easier in the unlikelihood of significant approval from currency traders for government intervention. Results from the survey indicate that their opinions on this issue are far from uniform. Thus, the focus of analysis of results from the survey is on the attitudes of currency traders towards official intervention in Hong Kong's financial markets, with the aim of uncovering the important factors that influence the dealers' attitudes towards government intervention. This would provide an indication of the extent of public support for intervention and likelihood of official intervention in the future if the $\mathrm{HK} \$$ were to be attacked in similar circumstances.

Results from the survey found that official intervention in financial markets received strong support from experienced financial workers with a deep attachment to Hong Kong. The more experienced they were and deeper was their attachment, the stronger was their support. Their support for intervention cannot be attributable simply to self-interest because

3. Shang-Jin Wei, Ligang Liu, Zhi Wang and Wing T. Woo, "The China money puzzle: will devaluation of the yuan help or hurt the Hong Kong dollar?" China Economic Review, Vol. 11 (2000), pp. 171-188.

4. Ibid. 
financial workers are financially astute and have diversified wealth portfolios that cut across different industries and regions. Financial workers in Hong Kong are not hostages to stocks listed on Hong Kong's financial markets. The survey suggests that those with long employment experience in Hong Kong had less faith in unfettered free markets and took into account more seriously the speculative aspects of markets and their periodic tendency to exhibit alternatively irrational exuberant and pessimistic behaviour. This article argues that there was also strong public support for intervention and the success of the HKMA's actions in 1998 ensures that official interventions in financial markets in Hong Kong are likely if they were to face similar speculative attacks in the future.

This article is divided into four sections. The first section provides a brief description of foreign exchange and derivatives markets in Hong Kong in 1998. The second explains the workings of Hong Kong's currency board and its role in maintaining the HK\$/US\$ peg. It analyses the weaknesses of the board and explains how speculators tried to attack the HK\$ in 1998 through foreign exchange and stock and futures markets, and how the Hong Kong authorities thwarted their actions. Section three presents results from the survey of currency traders and analysis of those results. We conclude in section four.

\section{Foreign Exchange and Derivatives Markets in Hong Kong ${ }^{5}$}

The Bank for International Settlements (BIS) organized a triennial survey of foreign exchange and derivative markets by 43 central banks and monetary authorities in 1998. The HKMA carried out the survey on Hong Kong markets for the BIS. Hong Kong ranked sixth among the economies surveyed in total foreign exchange transactions, dropping two positions since the last survey in 1995, with a global market share of 4 per cent after the UK (32 per cent), US (18 per cent), Japan ( 8 per cent), Singapore ( 7 per cent), Germany ( 5 per cent) and Switzerland (4 per cent). ${ }^{6}$ Table 1 shows the net turnover transactions of spot, forward and all foreign exchange transactions in Hong Kong in April 1995 and April 1998 of the HK\$ against the US\$ and other currencies. The table excludes the trades of the US\$ against all currencies other than the HK\$ and cross-currency trades (non-HK\$/non-US\$). The data in the table show that in the three years between 1995 to 1998 there was a significant increase in trade of the HK\$ against the US\$, especially in the forward market, increasing the shares of these trades in the total foreign exchange transactions in Hong Kong. In contrast, transactions in other currency trades in Hong Kong such as the US\$ against the Japanese yen and the Malaysian ringgit fell in that period. ${ }^{7}$ The fall in the other currency trades

5. Material in this section is drawn mainly from Anon, "Turnover of foreign exchange and derivatives markets in Hong Kong," Quarterly Bulletin (Hong Kong Monetary Authority, November 1998), pp. 54-64.

6. Ibid. p. 55 .

7. Ibid. 
Table 1: Net Turnover in Foreign Exchange Transactions (US\$ million) (Currency Composition)

\begin{tabular}{|c|c|c|c|c|c|}
\hline \multirow[b]{2}{*}{ Currency } & \multicolumn{3}{|c|}{$\begin{array}{l}\text { Average daily net turnover in } \\
\text { spot transactions }\end{array}$} & \multicolumn{2}{|c|}{ \% share } \\
\hline & April 1995 & April 1998 & $\%$ change & April 1995 & April 1998 \\
\hline \multicolumn{6}{|c|}{ HK dollar against: } \\
\hline US dollar & 3,612 & 4,516 & 25.0 & 10.5 & 14.6 \\
\hline \multirow[t]{2}{*}{ Others } & 959 & 921 & -4.1 & 2.8 & 3 \\
\hline & \multicolumn{3}{|c|}{$\begin{array}{l}\text { Average daily net turnover in } \\
\quad \text { forward transactions }\end{array}$} & \multicolumn{2}{|c|}{ \% share } \\
\hline Currency & April 1995 & April 1998 & $\%$ change & April 1995 & April 1998 \\
\hline \multicolumn{6}{|c|}{ HK dollar against: } \\
\hline US dollar & 10,674 & 12,968 & 21.5 & 19.2 & 27.3 \\
\hline Others & 60 & 307 & 411.7 & 0.1 & 0.6 \\
\hline
\end{tabular}




\begin{tabular}{lcccccr} 
& \multicolumn{3}{c}{$\begin{array}{c}\text { Average daily net turnover in } \\
\text { foreign exchange transactions }\end{array}$} & & \multicolumn{2}{c}{$\%$ share } \\
\cline { 2 - 3 } \cline { 6 - 7 } Currency & April 1995 & April 1998 & \% change & April 1995 & April 1998 \\
\hline HK dollar against: & & & & & \\
US dollar & 14,268 & 17,484 & 22.5 & & 15.8 & 22.3 \\
Others & 1,019 & 1,227 & 20.4 & & 1.1 & 1.6 \\
\hline
\end{tabular}

Note:

The last two columns are shares of trade of the HK\$ against the US\$ and other currencies in the total spot, forward and foreign exchange transactions in Hong Kong.

Source:

Quarterly Bulletin (Hong Kong Monetary Authority, November 1998), pp. 54-64, Tables 4, 5 and 6. 
reflected the downturn in economic activity in Hong Kong in 1998 because of the financial crisis. The reason behind the rise in HK\$/US\$ trades in Hong Kong's foreign exchange markets in the middle of the financial crisis was the high level of speculative activity against the HK\$ vis-à-vis the US\$.

\section{Hong Kong's Currency Board and Currency Speculation}

The HK\$/US\$ peg is maintained under a currency board arrangement (CBA). ${ }^{8}$ Currency boards were first introduced in the 19 th century to British colonies, with the first established in Mauritius in 1849. Hong Kong adopted a CBA in 1983. In the middle of Sino-British negotiations over the future of Hong Kong, loss of confidence in the then British colony led to a flight of capital from the colony, resulting in a 50 per cent depreciation of the HK\$ against the US\$. Stock and property prices collapsed and there were deposit runs from several financial institutions. A CBA was seen to be the best way for Hong Kong to achieve exchange rate stability, which is crucial for an economy, like Hong Kong, that is highly dependent on international trade and financial services. According to Mundell-Fleming, a fixed exchange rate regime, like a CBA, makes an economy lose its autonomy over domestic monetary policy. ${ }^{9}$ However, Hong Kong's policy makers considered this a small price for Hong Kong to pay because Hong Kong residents hold large amounts of foreign currencies and engage in currency substitution, which causes high exchange rate volatility. ${ }^{10}$ Moreover, domestic prices in Hong Kong are relatively flexible because of Hong Kong's small and open liberal economy, which reduces the need for a flexible exchange rate to facilitate macroeconomic adjustment.

What distinguishes a CBA from conventional currency pegs is that it is set up with clearly defined rules of operation specified by law. It is a system based on rules rather than discretion, which means that the fixed exchange rate cannot be changed easily. It is now an article of faith among the people of Hong Kong that the peg is central to their prosperity. As the chief economist of the Hong Kong Chamber of Commerce claimed: "It's not just a matter of banking confidence or business

8. For a in-depth discussion on currency boards, see Thomas J. T. Balino and Charles Enoch, "Currency Board arrangements: issues and experiences," Occasional Paper 151 (Washington DC: International Monetary Fund, 1997). See Joseph Yam, Review of Currency Board Arrangements in Hong Kong (Hong Kong: Hong Kong Monetary Authority, 1999) for a review of the CBA in Hong Kong. Material in this and the next paragraph is drawn largely from these two sources.

9. See Robert Mundell, "Capital mobility and stabilisation policy under fixed and flexible exchange rates," Canadian Journal of Economics and Political Science, Vol. 29 (1963), pp. 475-85 and J. Fleming, "Domestic financial policies under fixed and under floating exchange rates," IMF Staff Papers, Vol. 9 (1962), pp. 369-379.

10. For a discussion on currency substitution, see G. A. Calvo and C.A. Rodriguez, "A model of exchange rate determination under currency substitution and rational expectations," Journal of Political Economy, Vol. 85 (1977), pp. 617-624. 
confidence. It's also a big issue for people on the street: if the peg goes, it will be widely perceived as a big blow to Hong Kong." 11

Domestic currency in a CBA is backed by foreign assets and can only be issued against the available stock of official foreign exchange. In Hong Kong, the backing is normally more than 100 per cent, so that available foreign reserves are more than sufficient to back the domestic money supply at the fixed HK\$/US\$ rate. But if a speculative attack were to lower the backing to 100 per cent, further falls in domestic holdings of foreign exchange are automatically matched by equivalent falls in the domestic supply of money. The resulting rise in HK\$ interest rates would then induce a counter-flow of funds into $\mathrm{HK} \$$, maintaining the fixed HK\$/US\$ rate. However as pointed out by Tsang et al., if the exchange rate is fluctuating and if the market is unsure that the fixed rate would hold, higher interest rates will not induce a counter-flow of funds into $\mathrm{HK} \$ .{ }^{12}$ If this happens, in a classical CBA, cash arbitrage by the public will have to do the job of maintaining the fixed rate. The public would buy US\$ from the currency board with HK\$ at the lower official rate and then sell their US\$ for HK\$ at the higher market rate, bringing the market rate into line with the official rate. But cash-based arbitrage opportunities are limited in Hong Kong because Hong Kong is a modern financial economy with a small cash base. Hong Kong's currency board system thus lacked an important anchor to support the exchange rate and was vulnerable to currency speculation. The HKMA therefore had to rely on discretionary interventions as a substitute for cash arbitrage. ${ }^{13}$

During the Asian financial crisis, on 20 October 1997, after speculators had forced Taiwan to abandon defence of its dollar, they turned their attention to Hong Kong, dumping large amounts of $\mathrm{HK} \$$ on currency markets. Massive selling of the HK\$ (therefore massive buying of the US\$) by speculators, among which were local banks, reduced Hong Kong's foreign reserves under the control of the currency board to a level that triggered a massive fall in the supply of HK\$. The demand for HK\$ relative to its supply was so high that on 23 October, "Black Thursday," the overnight $\mathrm{HK}$ inter-bank rate offered rate ${ }^{14}$ shot up to 280 per cent. The high interest rate prompted the banks to sell US\$ back to the currency board for $\mathrm{HK} \$$ and relieved the tight $\mathrm{HK} \$$ liquidity in the interbank market. The HK\$/US\$ peg survived, but it faced even greater challenges a year later.

11. Ian Perkin, chief economist of the HK Chamber of Commerce quoted in the Business Times (Singapore), 2 December 1998, cited in Ding Lu and Qiao Yu, "Hong Kong's exchange rate regime: lessons from Singapore," China Economic Review, Vol. 10 (1999), p. 138.

12. Shu-ki Tsang, Chor-yiu Sin and Yuk-shing Cheng, "The robustness of Hong Kong's linked exchange rate system as a Currency Board Arrangement," revised paper presented at the 54th Meeting of the Econometric Society, Santiago de Compostela, Spain, 29 August-1 September 1999, p. 3.

13. Ibid. p. 8. See also Shu-ki Tsang, "Fixing the exchange rate through a Currency Board Arrangement: efficiency risk, systemic risk and exit cost," paper presented at the Sixth Convention of the East Asian Economic Association, Kitakyushu, Japan, 4-5 September 1998.

14. The interest rate that Hong Kong's banks charge one another for HK\$. 
In 1998, there were three concerted speculative attacks against the HK\$, in January, June and August. The attack in early August was the most serious. Donald Tsang Yam-kuen, Hong Kong's financial secretary, named the strategy of the speculators, "double play," that is a simultaneous dumping of $\mathrm{HK} \$$ and accumulating short positions in the stock and futures markets. ${ }^{15}$ Massive selling of $\mathrm{HK} \$$, like before, increased interest rates, which made holding $\mathrm{HK} \$$ more attractive relative to stocks, pushing further down stock prices that had already fallen by 50 per cent in the last ten months.

At the end of 1997, Hong Kong had foreign reserves of US\$92.8 billion, which was 7.1 times the monetary base, 54 per cent of GDP and 15 months of retained imports. ${ }^{16}$ In 1997 and 1998 Hong Kong had the world's third largest foreign exchange reserves after Japan and mainland China. ${ }^{17}$ Speculators therefore believed that Hong Kong had a good chance of defending the peg successfully. But even if the peg was successfully defended, they rationalized, they could still derive enormous gains in the futures markets by buying stocks at the lower future spot price to sell at the much higher forward price that they had secured. Speculators may lose marginally in the foreign exchange market but could realize significant gains on stock index futures. It was a win-win situation from the speculators' perspective.

Speculative attacks on the HK\$, which were largely prefunded offshore, pushed interest rates higher, adversely affecting investment and household demand. This further dampened Hong Kong's economy, which was already reeling from the effects of Asia's financial crisis, increasing unemployment and further undermining domestic and international confidence in the future of Hong Kong. Hong Kong's economy had contracted by 2.8 per cent in the first quarter of 1998 and was expected to contract a further 4 per cent or more in the second quarter. Unemployment had reached 4.8 per cent in August, the highest in 15 years. ${ }^{18}$ Speculative attacks on the HK\$ were increasing the economic and social costs of maintaining the currency peg.

On 14 August 1998, the Hong Kong government decided to act to counter the speculators in a way that was totally unexpected. On that day alone it spent, according to most estimates, HK\$3 billion (US\$385 million) to prop up the stock market. ${ }^{19}$ By the end of the month it had

15. Short positions mean selling stock forward, say three months in the future, in anticipation that the spot price in three months' time will be lower than the price that was agreed in the forward contract. This allows speculators to make a profit by buying at the lower future spot price and selling at the higher forward price.

16. Joseph Yam, "The Hong Kong dollar link," Hong Kong Trade Development Council Roadshow in Tokyo, 1998.

17. It lost the number three position in December 1998 to Taiwan but regained it in December 2000. At the end of that month, Hong Kong had foreign reserves of US\$107.5 billion compared to Taiwan's US\$106.74. See Enoch Yiu, "HK tops Taiwan in foreign currency," South China Morning Post, 9 January 2001.

18. The Economist, "Down and out in the fragrant harbour," 15 August 1998, p. 21. The Economist "Hong Kong: market force," 22 August, 1998, p. 58.

19. Alkman Granitsas, Henny Sender and Salil Tripathi, "Politics and the peg," Far Eastern Economic Review, 27 August 1998, p. 59. 
spent up to US\$15.1 ( $\mathrm{HK} \$ 118)$ billion of official reserves to purchase stocks, pushing stock prices up and preventing speculators from profiting from their short positions. ${ }^{20}$ The Hang Seng share index rose steadily in response to the actions of the HK government. On 14 August, the index rose 8.5 per cent, reversing the sharp falls of a fortnight earlier to $7,224.69$ points at the close of trading. On that same day, interbank interest rates fell by 0.5 to 0.75 per cent. ${ }^{21}$ By keeping the prices of stocks high, the HKMA forced speculators to pay high spot prices to meet their forward contracts, making many of them incur huge losses.

The Hong Kong government established the Exchange Fund Investment Limited (EFIL) in October 1998 to handle the sale of the stocks that it has acquired. The decision was made in mid-1999 to sell the stocks via an (Hang Seng) index-linked fund, the Tracker Fund of Hong Kong (TraHK). An initial public offering (IPO) of a portion of the stocks was set on 25 October and the first day of trading on 12 November 1999. The IPO was a success. Applications totalled over HK\$30 billion, more than three times the original indicative offer size. ${ }^{22}$ Eventually HK $\$ 33.3$ billion worth of stocks were sold, making it the largest public offering in Asia outside Japan. ${ }^{23}$ On its first trading day, TraHK gained 10 per cent on its offering price. ${ }^{24}$ Following the success of the IPO, the Hong Kong government planned to sell $\mathrm{HK} \$ 12$ billion of the remaining stocks every quarter. $^{25}$ By July 2000, HK $\$ 66.6$ billion worth of stocks had been disposed of through TraHK. ${ }^{26}$ In April 2001, Donald Tsang Yam-kuen proudly announced that the profit of EFIL as of 16 April stood at HK\$110 (US\$14.1) billion. ${ }^{27}$

As events transpired, the Hong Kong government ultimately made a profit from its actions. Nevertheless, its unprecedented intervention in the stock market was controversial and led to accusations from many quarters that it had set a dangerous precedent, threatening Hong Kong's reputation as having one of the world's freest economies and being a key financial centre. At that time, Milton Friedman, the doyen of free market economics, called the actions of the Hong Kong government "insane" and the Heritage Foundation claimed that they threatened Hong Kong's position as the world's freest economy. In the words of The Economist, "the manoeuvre has blemished Hong Kong's record of non-intervention in the stock market since 1987's global crash." ${ }^{28}$ Far Eastern Economic Review, the premier business magazine in Asia, was no less critical: "But the

20. Hong Kong's financial secretary, Donald Tsang Yam-kuen, revealed the figure. See Enoch Yiu, "Tsang gets back crisis billions," South China Morning Post, 17 April 2001, http://biz.scmp.com/ZZZ64SKY4LC.html. Rowan Callick, "Crisis finally takes toll on Hong

Kong," Australian Financial Review, 8 September 1998, gave a much lower figure of US\$9.5billion.

21. Granitsas, Sender and Tripathi, "Politics and the peg," p. 59.

22. South China Morning Post, 6 November 1999.

23. South China Morning Post, 9 November 1999.

24. South China Morning Post, 13 November 1999.

25. South China Morning Post, 16 December 1999.

26. South China Morning Post, 8 July 2000.

27. See Yiu, "Tsang gets back crisis billions."

28. The Economist "Hong Kong: market force." 
intervention cost the government more than just money - it cost credibility. By intervening, the government casually tossed aside the carefully cultivated free-market ethics that have distinguished Hong Kong from other Asian markets." ${ }^{29}$ The magazine quoted several bankers, all of whom were highly critical of the intervention. Granitsas et al. believed that the Hong Kong government's actions might be effective in the short run but would be ineffective in the long run, resulting in the ultimate forced end of the HK\$/US\$ peg. ${ }^{30}$ There were also criticisms that many of the public who bought into TraHK mistakenly believed that the Hong Kong government guaranteed its rate of return, artificially inflating public demand for it. ${ }^{31}$

\section{Survey of Currency Traders}

Since market sentiments were a crucial factor in determining the outcome of those speculative attacks, the views of major players in Hong Kong's currency markets - those working in foreign exchange departments in financial institutions - would be crucial. During the Asian crisis, the fate of the $\mathrm{HK} \$$ was likely to depend more on market sentiments and herd mentality than on economic fundamentals. Thus it would be useful to survey these workers on their views of the HK\$/US\$ peg and official market intervention to defend the peg. Unfortunately we were unable to conduct a survey while the intervention was in progress. We were able to conduct one only after the Asian crisis was over, in October 2000. A survey of financial players at the height of official market intervention would indicate the state of market psychology at that time, while another survey after intervention would indicate the probable response to a similar financial crisis in the future. Results from the two surveys could have been different. From a policy analysis perspective, the latter survey is more informative. To derive any policy implication from the survey it would be better to conduct it some time after the Hong Kong government's intervention, to allow interviewees some time to reflect upon its consequences, rather than to conduct it at the height of the crisis. Whether the HKMA will repeat its actions of defending the HK\$/US\$ peg through financial market intervention in the future depends on the evaluations of market players of its past actions as well as the general public's perception on whether its actions have been a success or a failure. While the Hong Kong and international media were almost unanimous in their condemnation of the Hong Kong government's actions, the opinions of the people who were most involved in currency dealing were very mixed. This was borne out by the survey undertaken by the authors of this article of currency traders and related professionals who were working in Hong Kong in the midst of the speculative attacks launched against the HK\$.

Two research assistants of the authors made enquiries with the public

29. Granitsas, Sender and Tripathi, "Politics and the peg," p. 59.

30. Ibid.

31. South China Morning Post, 9 December 1999. 
relations' departments of licensed banks listed in the November 1998 issue of the Quarterly Bulletin of the HKMA to find out which banks had a foreign exchange (forex) department and the size of each department. A total of 110 banks (Hong Kong and foreign) were found to have forex departments. Some of the banks had since closed. The remaining banks were divided into three categories according to size by employment. The 30 large banks were each sent five questionnaires, the 40 middle ones were sent three each, and two were sent to each of the 40 small banks. In all a total of 350 questionnaires were sent to the heads of forex departments of the banks. The questionnaires were in both English and Chinese (complex characters) because the majority of the respondents were local Hong Kong Chinese who understood complex, but not simplified, Chinese characters. Some respondents answered the open-ended questions in English and others in Chinese. As an inducement for the questionnaires to be returned, a promise was made that results of the survey would be sent to those who provided their postal or email addresses.

Of the 350 questionnaires, 77 were returned, giving a response rate of 22 per cent. Reminder letters were sent and another 10 responses were received, giving a final response rate of 25 per cent. After removing those who had worked less than a year in Hong Kong by October 1998, a total of 77 responses were left. As shown in Table 2, a large number of those who responded had worked for more than five years in Hong Kong or Macau. A staggering 60 per cent had more than 10 years' experience. This is not surprising when one looks at Table 3. More than 50 per cent

Table 2: Length of Service in Hong Kong/Macau by October 1998

\begin{tabular}{lc}
\hline Length of service & Per cent \\
\hline Longer than 3 years & 87.0 \\
Longer than 5 years & 75.3 \\
Longer than 10 years & 59.7 \\
Longer than 15 years & 32.5 \\
Longer than 20 years & 10.4 \\
\hline
\end{tabular}

Table 3: Current Positions (2000)

\begin{tabular}{lr}
\hline Positions & Per cent \\
\hline Forex trading manager & 20.0 \\
Chief trader & 8.0 \\
Senior trader & 18.7 \\
Trader & 17.3 \\
Economist/analyst & 4.0 \\
Others & 32.0 \\
All positions & 100.0 \\
\hline
\end{tabular}


of those surveyed held positions of senior currency trader or higher. ${ }^{32}$ The majority of the respondents worked for Hong Kong or Macau financial institutions (38 per cent). ${ }^{33}$ The next largest group worked for EU institutions (10 per cent), followed by institutions from Japan ( 8 per cent) and the US and Canada (6 per cent). Most of the respondents chose to remain anonymous, perhaps not wanting their private opinions to be associated with their employers.

An interesting question posed by many analysts during the Asian crisis was whether the HK\$ would have devalued had the RMB devalued. Among the many reasons put forth by analysts as to why the Chinese government would not devalue the RMB was that such a devaluation would make investors lose confidence in the HK\$ and lead to capital flight, undermining confidence in the future of Hong Kong. This would, as the reasoning goes, cause the Chinese government to lose face since Hong Kong had reverted to Chinese sovereignty only one year earlier. Other analysts, such as Wei et al. discussed above, thought otherwise and argued that there was no obvious reason why the HK\$ should follow movements in the value of the RMB. Table 4 shows that a small majority of respondents (50.7 per cent) believed that devaluation of the RMB would inevitably led to a devaluation of the $\mathrm{HK} \$$. But a significant majority (70.2 per cent) believed that if RMB devaluation had occurred it would mean the end of Hong Kong's CBA and the HK\$ would be floated (Table 5). This is a very interesting result because it shows that a

Table 4: Likelihood of Devaluation of HK\$ had the RMB Devalued During the Crisis

\begin{tabular}{lr}
\hline Likelihood & Per cent \\
\hline Very Likely & 14.3 \\
Likely & 36.4 \\
Don't Know & 6.5 \\
Unlikely & 36.4 \\
Very Unlikely & 6.5 \\
& 100.0 \\
\hline
\end{tabular}

Table 5: Likelihood of the End of the CBA if the HK\$ Had Devalued

\begin{tabular}{lr}
\hline Likelihood & Per cent \\
\hline Very Likely & 22.1 \\
Likely & 48.1 \\
Don't Know & 9.1 \\
Unlikely & 20.8 \\
Very Unlikely & 0.0 \\
& 100.0 \\
\hline
\end{tabular}

32. Most of those in the other category were managers in forex departments.

33. Virtually all of these would be Hong Kong financial institutions. 
sizeable of number those interviewed (20 per cent) believed that the HK\$ was sufficiently strong to be able to hold its value without the support of the HK\$/US\$ peg.

Those who responded by saying that devaluation of the RMB was unlikely or most unlikely to cause a devaluation of the $\mathrm{HK} \$$ and offered explanations for their responses mainly gave as their reasons the independence of Hong Kong's and mainland China's monetary systems from one another, and the large foreign reserves of Hong Kong. Those who thought otherwise mentioned the close integration of the Hong Kong and mainland economies. Interviewees who believed that independence of the two monetary systems made it unlikely that the HK\$ would devalue in response to RMB devaluation were referring to the fact that Hong Kong, unlike mainland China, has a strong financial system with a well established and effective system of prudential supervision. Locally incorporated banks in Hong Kong have more than adequate capital adequacy ratios, averaging 17 per cent, and problem debt ratios of less than 2 per cent. ${ }^{34}$ Mainland China's financial system, on the other hand, is in a poor state. Banks have low capital adequacy ratios and problems with non-performing loans. ${ }^{35}$ Those interviewees who mentioned the close integration of the Hong Kong and mainland economies were concerned with Hong Kong's loss of trade competitiveness vis-à-vis mainland China should the RMB be devalued.

"HK\$ [is] backed by US or foreign currency under pegged system while the RMB is not." (20 years in HK, chief trader) $)^{36}$

"HK has huge foreign reserves and no foreign debt. HKMA should be able to use the huge reserves to defend HK dollar during crisis." (20 years in HK, forex trading manager)

"The devaluation of CNY would show that Chinese government no longer supports the idea of pegged currency. Without their support, HKMA could not handle the political pressures in a crisis." (nine years in HK, chief trader)

"Basically I think RMB is proxy of HK\$. Given the size and influence of the Chinese economy, it will just overwhelm HK." (eight years in HK, senior trader)

"Because their economies are integrated." (19 years in HK, forex trading manager)

Contrary to our expectations, more were in favour of the Hong Kong government's actions to defend the HK\$/US\$ peg by directly intervening in the stock and forward markets than those who were against (49.4 to 33.8 per cent). A significant number (17 per cent) were undecided (Table 6). As expected, respondents who were opposed to the Hong Kong government's actions gave as their reason that the actions would have an

34. Yam, "The Hong Kong dollar link," p. 3.

35. Leong H. Liew, "China's economic reform experience: the end of a Pareto-improving strategy," China Information, Vol. 14, No. 2 (2000), pp. 140-42. See Nicholas R. Lardy, China's Unfinished Economic Revolution (Washington DC: Brookings Institution Press, 1998) for an in-depth analysis of China's financial system.

36. Some respondents did not provide detail of their position within their employer organizations. 
Table 6: HK Government Intervention in Stock and Futures Market

\begin{tabular}{lc}
\hline Desirability & Per cent \\
\hline Very Necessary & 16.9 \\
Necessary & 32.5 \\
Don't Know & 16.9 \\
Wrong & 23.4 \\
Very Wrong & 10.4 \\
& 100.0 \\
\hline
\end{tabular}

adverse effect on Hong Kong's reputation as a free market economy and important financial centre.

"Once involved, always involved. There is heightened risk for government, HKMA to intervene in [the] future, undermining [the] free economy."

"The market became inefficient and was improperly manipulated." (22 years in HK, senior trader)

"I believe in 'invisible hand' in free economy." (15 years in HK)

"That was unfair for investors as referees suddenly became participants." (six years in $\mathrm{HK}$, economist)

"It jeopardizes the reputation of Hong Kong as a prominent financial centre." (eight years in $\mathrm{HK}$, forex trading manager)

"People will now be suspicious (huaiyi) of the authorities' promise (chengnuo) of a free market [in Hong Kong]." (Trader)

"It just upset the market balance! HK is no longer a 'free' economy any more." (eight years in $\mathrm{HK}$, senior trader)

"Invisible hand should apply in a free economy/market." (five years in HK)

"HK\$ is just a proxy of the yuan in the long run. Without peg, we could have been much better. Peg is an obstacle to recovery. After all, why there are speculators? Because we have been maintaining an unreasonable exchange system." (seven years, senior trader)

Respondents who defended the government's actions reasoned that the Hong Kong economy would be in serious trouble had the government not intervened.

"If not, the whole HK will collapse." (38 years in HK)

"Stop speculation politically. Why Western countries only challenge HK but [not] Taiwan?" (20 years in HK)

"In order to protect $\mathrm{HK} \$$ and stabilize HK economy, pre-emptive measure is a must." (22 years in HK, senior trader)

"Short-term speculation had severely affected the whole economic system. The destruction brought about by the speculation was irrational (fei lixing). This is not justified given the actual economic situation. Intervention is a correct method to 
regulate this disequilibrium (tiaojie shiheng)." (19 years in HK, forex trading manager)

"At that time, the choice of available methods was limited. Speculation could lead to a frightening outcome (kepa de houguo), closing markets. HK's status as a financial centre could have ended." (12 years in HK, forex trading manager)

"Speculation could leave behind serious economic ills (jingji de yizheng)." (22 years in HK, senior trader)

"The decision was vindicated by subsequent events, but it was not the only choice possible. Unusual times call for extraordinary actions (feichang shiqi zuochu feichangshi)." (three years in HK, trader)

"Although the actions were criticized, I believe that the HK government had a plan (you jihua)." (17 years in HK)

An interesting question is what factors explain the answers of respondents. Tables 7 and 8 provide possible answers to this question. Table 7 shows that the number of years of experience working in Hong Kong is an important factor. Those who had worked ten or more years were significantly more likely to approve the official intervention in stock and forward markets than those who had under ten years' experience. Correspondingly, those who had ten or more years' experience were significantly less likely to be critical of government intervention than those with fewer years of experience.

Table 7: Work Experience and Desirability of Government Intervention

\begin{tabular}{lcc}
\hline Desirability & $\begin{array}{c}\text { Under 10 years } \\
\text { Per cent }\end{array}$ & $\begin{array}{c}\text { 10 or more years } \\
\text { Per cent }\end{array}$ \\
\hline Very Necessary/Necessary & 22.6 & 61.0 \\
Don't Know & 9.7 & 17.4 \\
Wrong/Very Wrong & 67.7 & 26.7 \\
& 100.0 & $100.0^{*}$ \\
\hline
\end{tabular}

Note:

*Total does not add up to 100 because of rounding errors.

Table 8: Ownership, Education and Approval of Government Intervention

\begin{tabular}{lcc}
\hline Country/region & $\begin{array}{c}\text { Employment } \\
\text { Per cent }\end{array}$ & $\begin{array}{c}\text { Education } \\
\text { Per cent }\end{array}$ \\
\hline EU & 50.0 & 50.0 \\
Hong Kong & 58.6 & 54.0 \\
Japan & 33.3 & - \\
North America, Australia, NZ & 12.5 & 26.3 \\
\hline
\end{tabular}


There are several plausible reasons why lengthy working experience is likely to correlate with approval of government intervention. Of the 77 final respondents, 72 (94 per cent) received most of their primary and secondary education in Hong Kong. This suggests that most of the respondents had roots in Hong Kong and therefore were likely to have a stake in its economy. In other words, even if ideologically they believe in a free market, they faced a dilemma between their ideological commitment and their own self-interest. The longer they had worked, the larger the financial asset portfolio they were likely to have accumulated and the higher the likelihood they would favour official intervention to prop up the stock market. However, given that professional workers in the finance industry are generally financially astute and aware of the many possibilities of hedging against risk, it is highly probable that they would have diversified their wealth portfolio and placed some of their wealth in non-Hong Kong assets. Therefore, another reason could simply be that those with longer working experience had less faith in unfettered free markets and took into account more seriously the speculative aspects of markets and their periodic tendency to exhibit alternatively irrational exuberant and pessimistic behaviour. They believed that the official short-term intervention in Hong Kong financial markets was necessary in the long run to maintain efficient free markets.

The source of the highest educational qualification of respondents and the country of origin of their employers had an influence on whether they approved government intervention or not (Table 8). Those who received their highest qualification from Hong Kong and the EU and were employed by Hong Kong and EU financial institutions were more likely to approve government intervention than those who received their highest qualification or whose employers originated from North America, Australia and New Zealand. Only 13 per cent of respondents employed by institutions from the latter group of countries and 26 per cent who received their highest qualification there were in favour of government intervention, compared to 59 per cent of those who were employed by Hong Kong financial institutions and 54 per cent of those who received their highest qualification from Hong Kong. This was not because respondents who worked for the North American, Australian and New Zealand institutions or received their highest educational qualification from those countries were expatriates from those countries: only one of them received most of his/her primary and secondary education outside Hong Kong. A more likely explanation is that Hong Kong institutions were far more dependent on domestic lending for their profits than the foreign institutions and therefore were more concerned with the level of domestic economic activity in Hong Kong, which was susceptible to a negative wealth effect from falling values in the stock market. While Hong Kong employees of financial institutions largely believed in the free market, the intellectual foundation in the minds of these employees was likely to be reinforced if they had received formal academic training in North America, Australia, New Zealand (and the United Kingdom), which are the main centres of training in free market economics. 


\section{Conclusion}

Hong Kong's CBA was reformed in the light of the financial crisis to make the HK\$ more resilient against speculation. In 7 September 1998 the HKMA introduced several measures to strengthen the HK\$/US\$ peg. The measures were designed to widen the coverage of convertibility of the CBA from bank notes to the whole monetary base and to enlarge the monetary base. Before the introduction of these measures, the HKMA carried the whole burden of protecting the peg. Cash arbitrage was ineffective and the HKMA had to intervene directly to protect the peg, losing foreign exchange reserves in the process. Under the new CBA, currency arbitrage between the market and official exchange rate takes place electronically through interbank settlement with the HKMA. ${ }^{37}$ No exchange of cash is necessary. Extending the coverage of convertibility brings in self-interested arbitragers that act to bring the market rate into line with the official exchange rate; the HKMA does not have to fight speculators alone. And enlarging the monetary base ensures that there is appropriate liquidity to minimize any effect on interest rates. The reform of the CBA, while not ruling out future official interventions in financial markets, reduces the likelihood that the HKMA would be forced to undertake another intervention on a scale similar to that undertaken during August 1998. However, there are still many analysts who believe that the current CBA will still have to rely partially on monetary policy tools rather than relying completely on the CBA's "self-stabilizer." 38

The HKMA decision to intervene in stock and forward markets in August 1998 to beat off speculators betting against the HK\$ was controversial. Its actions were later applauded because they were successful in protecting the peg without adversely affecting Hong Kong's long-term reputation as one of the world's freest economies. In 2001, the Heritage Foundation in Washington DC and the Fraser Institute in Vancouver ranked Hong Kong as the world's most economically free jurisdiction. ${ }^{39}$ If the HKMA had lost its fight with the speculators and its intervention had cost the government huge financial losses, the judgement could have been different. What is interesting from an academic perspective is how the speculators attempted to execute what they thought was a low risk "double play" strategy against the HK\$ and the counter strategy of the HKMA, which, by violating the rules of the free market, was able to flat foot the speculators. From a non-technical perspective, it is interesting to examine the attitudes of those in Hong Kong working in the trading of foreign exchange. Contrary to prior expectation, there was not universal support for unfettered free markets among currency dealers. Instead, more currency dealers were in support of the HKMA's actions than those who were against. Identification with Hong Kong through length of work

37. For detailed discussions in the September 1998 measures see Tsang, Sin and Cheng, "The robustness of Hong Kong's linked exchange rate system," pp. 8-10 and Shu-ki Tsang, "Technical note on the seven measures," unpublished note, 14 November 1998.

38. One who holds this view is Yitao Fang, "The theory and practice of the linked exchange rate system in Hong Kong," Hong Kong Economic Journal, No. 266 (1999), pp. 83-88.

39. Suzanne Harrison, "Global survey shows Hong Kong still the best place to feel free," South China Morning Post, 23 April 2001, http://biz.scmp.com/ZZZUQJ15SLC.html 
experience, source of education and employment were found to be important factors influencing attitudes towards government intervention. In summary, those who were likely to approve market intervention had longer work experience in Hong Kong (ten years or longer), were likely to have received their highest educational qualification in Hong Kong, and worked for a Hong Kong, rather than a North American, Australian or New Zealand institution. Thus official intervention in financial markets received strong support from financial workers with a strong attachment to Hong Kong. From this one could infer that there was also strong popular support for intervention among ordinary permanent residents of Hong Kong from outside the finance sector. This together with the significant profit made by Hong Kong's monetary authorities during their market intervention suggest that the monetary authorities will not hesitate to intervene in financial markets when faced with similar speculative attacks on Hong Kong financial markets in the future. 